\title{
3 Urbanization economies, proximity dimensions and productivity
}

\author{
A family firm perspective
}

\author{
Rodrigo Basco, Stefano Amato, \\ Silvia Gómez-Ansón and Andrea Calabrò
}

\section{Introduction}

After more than three decades of research on family businesses, one of the main unresolved research questions revolves around why family and non-family firms differ in terms of behaviour and performance. The most common answer is that family involvement in business affects the way an organisation is owned, governed, and managed, thereby causing family and non-family firm behaviour, performance, and survival to differ. Even though extensive research has attempted to explain, justify, and predict firm performance differences between family and non-family firms, the results are still contradictory (Basco, 2013; Mazzi, 2011).

Family business researchers have built a new body of knowledge to explain differences between family and non-family firms by investigating the family's effect on the firm. More specifically, these scholars have argued that the dominant coalitions in family and non-family firms have different goals (Williams, Pieper, Kellermanns, \& Astrachan, 2019). In the former, owner families imprint their unique goals on their firms, such as their intentions to transfer the ownership from one generation to another, to embrace and support family members around economic projects, and to preserve and sustain their family image and reputation across time (Aparicio, Basco, Iturralde, \& Maseda, 2017). Even though some of the differences between family and non-family firms originate from the interrelationship between the family and business domains, family business research is still contextless (GomezMejia, Basco, Müller, \& Gonzalez, 2020; Krueger, Bogers, Labaki, \& Basco, 2020), with context being defined as 'circumstances, conditions, situations, or environments that are external to the respective phenomenon and enable or constrain it' (Welter, 2011, 167). Specifically, scholars have given insufficient attention to how and to what extent family and non-family firms are affected by and able to affect context. Consequently, a future challenge for the field is to explore and interpret how contextual dimensions (e.g., spatial, social, institutional, and temporal), insofar as they are accounted for, shed new light on family firms' heterogeneity. 
Focusing on differences in productivity between family and non-family firms, we explore the contingent effect of the size of the municipalities in which firms dwell. We focus on urban settings for two main reasons. First, municipalities conflate spatial and social relationships in administratively bounded areas, hence creating well-defined territories (Bathelt \& Gluckler, 2003). Second, urban areas are a source of externalities (i.e., urbanisation economies) for the firms located within them, as reflected in these firms' static (e.g., higher profitability, productivity) and dynamic (e.g., higher innovative capacity) advantages compared to firms located elsewhere (Capello, 2002). Our main conjecture is that due to different family and non-family firm specificities, neither is a superior form of organisation in terms of productivity; however, for both types, productivity depends on firms' ability to exploit economies of proximity and urban agglomerations. Following the so-called 'regional familiness approach' (Basco, 2015), we argue that family firms, which are more locally embedded in their home territories than non-family firms, are better positioned to exploit proximity dimensions as vectors of territorial competitiveness because they can create particular economic, social, and emotional connections within their local socioeconomic milieus (Boschma, 2005). Therefore, the specificities of family firms give them locational advantages over their non-family counterparts when operating in small municipalities. In small municipalities, the embeddedness relationships developed business families both internally (i.e., among family members) and outside their organisational domains (i.e., in their local settings) substitute for the lack of spatial agglomerations.

We test our conjecture on a large panel dataset of Spanish manufacturing firms covering the 2002-2015 period. Our empirical evidence reveals a negative association between municipality size and the productivity of familymanaged firms. In particular, being located in a large urban setting is a source of diseconomies of agglomerations for family-managed firms. As such, they are better suited to exploit highly embedded contexts, such as small municipalities. Accordingly, we address the call made by Stough et al. (2015) to link the research fields of regional development and family business by exploring the relationship between spatial-temporal context and the nature of the firm to better understand firm growth in terms of productivity. In particular, by emphasising the spatial dimension of embeddedness (Hess, 2004) - that is, by anchoring economic action in territorially bounded networks of social relationships-our book chapter offers new evidence on how family firms are distinctively affected by their immediate surroundings.

\section{Theoretical background}

Family business research has mainly focused on the family-business relationship to explain differences in firm behaviour and firm performance between family and non-family firms. The primary argument to explain the specificities comes from the family firm goal approach (Aparicio et al., 2017; 
Basco, 2017). According to this approach, family firms are able to pursue multiple goals that combine economic and non-economic orientations as well as business and family orientations. Since organisation goals alter the reference point for decision making, we expect that the reference point used by family firms is different than that used by non-family firms (GomezMejia, Cruz, Berrone, \& De Castro, 2011).

Beyond extensive research taking an internal view (i.e., how the interplay between the family and business domains shapes firms' behaviour) to explain family and non-family performance differences, existing empirical evidence is still contradictory, and there is no clear understanding of whether the family firm is a superior form of organisation (Mazzi, 2011). The main issue is that family business research is contextless (James et al., 2020) that is, the spatial, social, institutional, and temporal dimensions of context have usually been overlooked in favour of the traditional internal view. To address this research gap, Amato, Basco, and Lattanzi (2020) recommend accounting for context to better interpret differences between family and non-family firms.

Context is a dimension that can both constrain and bolster firm competitive advantages and performance while simultaneously explaining firm heterogeneity (Amato, Basco, \& Lattanzi, 2020). This line of research is gaining importance in family business studies, and recent research has shown that firm differences in terms of performance and behaviour vary across socio-spatial contexts, such as rural and urban areas (Backman \& Palmberg, 2015; Baù et al., 2019), municipalities (Amato, Basco, Gómez-Ansón, \& Lattanzi, 2020), and regional settings (Adjei, Eriksson, \& Lindgren, 2016). Consequently, context matters.

\section{Regional familiness: an urban perspective}

Context matters because family and non-family firms differ in the extent to which they are 'anchored' to the territories in which they dwell (Backman \& Palmberg, 2015). While the economic link with territory defines how firms behave to exploit economic opportunities, family firms also usually develop specific social and emotional connections with their home territories (Smith, 2016). However, family firms' social and emotional attachments to their territories are not necessarily what make them perform differently from non-family firms; rather, these performance differences stem from family firms' ability to either exploit the advantages offered by or overcome the constraints inherent to a given location (Capello, 2002). The regional familiness approach, which encompasses 'the embeddedness of family businesses in social, economic, and productive structures within a spatial context' (Basco, 2015, 260), provides a theoretical explanation to link the study of family firms and regions.

The interpretation of space as 'diversified-relational' has restored the concept of external (or agglomeration) economies as sources of territorial 
competitiveness (Capello, 2009). The concentration of economic activity in spatially bounded areas gives rise to advantages for firms in the form of reduced production and transaction costs, enhanced efficiency of production factors, and increased innovative capacity. The term 'external' means that agglomeration economies are beyond firms' control and typically result from the presence of collective action among other firms and institutions, thus making them external to a focal firm but internal to either the industry or urban concentration (Parr, 2002).

Urban spaces are generally regarded as localities in which agglomeration economies occur. In particular, the local diversity of cities facilitates access to a qualified and diversified workforce, various infrastructure, a variety of facilities, and - even more importantly - to complementary knowledge, with industry diversification fostering firms' productivity and innovation performance (Galliano, Magrini, \& Triboulet, 2015; Jofre-Monseny, MarínLópez, \& Viladecans-Marsal, 2014). Hence, a diversified spatial setting typically leads to increasing returns by giving rise to so-called 'urbanisation economies', or 'Jacobs externalities'. A city arises as a spatial cluster of productive and residential activities (Parr, 2007). The concentration of a mix of sectors and diversified activities, the density of contacts that develop within them, and the easy access to advanced information and knowledge are clear advantages arising from being located in an urban setting that affect the productivity of the firms situated therein (Capello, 2002). At the same time, cities are able to generate 'dynamic' advantages (Jofre-Monseny et al., 2014). In particular, urban settings are characterised by shared values, common codes of behaviour, a sense of belonging, and mutual trust-all of which play a significant role in reducing uncertainty and in the socialisation process of knowledge development and collective learning that affects the innovativeness of co-located firms (Capello \& Faggian, 2005).

Urbanisation economies are generally regarded as being dependent upon the overall scale of the respective city (Fu \& Hong, 2011), with urban size being closely related to industrial diversity (Gao, 2004). That said, it is reasonable to ask whether firms benefit equally from urbanisation economies or, conversely, whether being located in an urban setting is a source of differential advantages or disadvantages for some firms and not for others. For instance, while city size has been found to affect small firms' productivity due to their higher reliance on a more diversified external environment than larger enterprises (Fu \& Hong, 2011; Henderson, Kuncoro, \& Turner, 1995), in small spatial settings, where access to agglomerations is more restricted, firm performance is strongly dependent upon proximity dimensions as conduits of interactive learning, cooperation, and knowledge exchange (Gordon \& McCann, 2000). However, particular types of firms (e.g., family-managed firms) may have a greater ability than others to leverage proximity dimensions in certain spatial contexts, such as cities.

Geographical proximity, which refers to the physical distance between economic actors (e.g., customers and suppliers) and regional factors (e.g., raw materials for production processes), seems to be important for any firm, 
including family and non-family ones. Being close to raw materials, customers, suppliers, and sources of knowledge could be considered an advantage that any firm can exploit. In particular, research has argued that geographical proximity is a key element for the promotion of externalities (Martin \& Simmie, 2008). However, not all firms are able to capitalise on the condition of being geographically close to each other, which is a necessary but insufficient condition to improve communication and trust among economic actors and which ultimately affects the efficiency of economic activity. Geographical proximity has to be lubricated with additional dimensions of proximity, such as cognitive and social proximity, which mirror feelings of similarity with and belonging to a given location, respectively (Lähdesmäki, Siltaoja, \& Spence, 2019).

While cognitive proximity refers to "the similarity of the subjective mental framework of actors and the tacit and codified knowledge owned by actors' (Westlund \& Adam, 2010, 112), social proximity refers to socially embedded relationships among agents based on trust and reciprocity derived from friendship, kinship, and experience (Boschma, 2005). For family firms, cognitive proximity is manifested through the emotional connection that business families are able to develop within their home territories. It is through this attachment that knowledge related to business flows and consolidates economic activity, thus enabling family firms to exploit competitive advantages from being family firms. Alongside cognitive proximity, social proximity seems to be a family-inherited condition stemming from families' long-standing presence in their territories (Cucculelli \& Storai, 2015). Family members bring social and kinship relationships to their firms, which help them exploit economic opportunities, ease the exchange of tacit knowledge, and reduce opportunistic behaviours (Baù et al., 2019). Hence, we expect that cognitive and social proximity reinforce each other to foster the economic activity in a given location.

Even though family firms seem to be positioned to uniquely exploit the benefits of social and cognitive proximity, their outcomes depend on the size of the spatial contexts in which they dwell (Martin \& Simmie, 2008). In particular, municipality size could constrain or broaden family firms' ability to transform their social and emotional embeddedness into superior performance. In small municipalities, where access to urbanisation economies is more restricted (Fu \& Hong, 2011; Gordon \& McCann, 2000), firms have to develop high-trust, cooperative, and reciprocal relationships both among their members and with external networks of local actors (i.e., local communities) to facilitate the economic activity. In this context, because of their emotional and social connections, family firms are in a superior position to benefit from interactive learning and knowledge exchange both within and outside their organisational boundaries (Adjei et al., 2016). On the other hand, in large urban settings, firms can benefit from Jacobs externalities such that family firms' competitive advantages appear to vanish, and any firm can exploit the externalities stemming from knowledge spillovers, a large pool of skilled labour, and increased efficiency in labour market matching (Galliano, Magrini, \& Triboulet, 2015). 
Hence, while in small urban settings, family firms' unique physical, social, and emotional connections substitute for the shortage of external agglomerations, their comparative locational advantages disappear as municipality size increases. That said, our conjecture is that family firms located in small municipalities have higher performance than their non-family counterparts. Therefore, we propose the following:

Hypothesis 1: Municipality size affects the performance of familymanaged firms in such a way that the larger the municipality in which a family firm dwells, the lower its productivity.

\section{Method}

\section{Data and variable}

To test our hypothesis, we rely on micro-data obtained through a survey of a representative sample of Spanish manufacturing firms. The survey, known as Encuesta sobre Estrategias Empresariales (ESEE, or Survey on Business Strategies), is conducted yearly by the SEPI Foundation in collaboration with the Ministry of Industry, Trade and Tourism of Spain. ESEE is oriented toward capturing information about firms' strategies, technological activities, manufacturing processes, markets served, and employment. The sample's representativeness is ensured by combining exhaustiveness and random sample criteria. In particular, while all companies with more than 200 workers are surveyed, firms employing 10-200 workers are selected based on stratified, proportional, and systematic sampling. ${ }^{1}$ The final sample includes 3,331 firms distributed across 20 different manufacturing industries (NACE Rev. two-digit level) ${ }^{2}$ and 17 Spanish autonomous communities (NUTS 2). ${ }^{3}$ It consists of 21,573 firmyear observations for the 2002-2015 period.

The dependent variable used in this study is labour productivity, defined as per capita value added (Adjei et al., 2016). We take the log of the values to reduce the skewness of the distribution.

The main exploratory variable is represented by the family status of the firm. As the definition of 'family firm' is a matter of longstanding debate among researchers (Mazzi, 2011), we adopt the so-called 'demographic approach' to identify family firms. This approach considers the involvement of a family in a firm - in its ownership, control, and management-as a sufficient condition to capture families' influence on businesses (Basco, 2013a). Since ESEE reports the number of owners and relatives holding management positions, we define a family firm as any firm in which two or more members of the controlling family hold managerial positions in the company. Therefore, we employ a binary variable coded 1 when the firm is family managed and 0 otherwise. To capture urbanisation economies, our moderator variable, we consider the size of the municipality in which the firm $i$ is located (Fu \& Hong, 2011). In particular, ESEE reports a categorical 
variable based on five different municipality sizes: fewer than 2,$000 ; 2,001-$ 10,$000 ; 10,001-50,000 ; 50,001-500,000$; and more than 500,000 inhabitants. ${ }^{4}$

Additionally, we control for a set of firm-level characteristics that potentially affect the level of productivity. To account for time-invariant heterogeneity across industries and regions, we include a series of categorical variables corresponding to the NACE two-digit code level and to the Spanish autonomous communities in which firms have their headquarters, respectively. Finally, we use a series of categorical variables to control for the years associated with each observation. Table 3.1 summarises the variables employed in the study.

Table 3.1 Description of variables

Variables Description

Dependent variable

Labour productivity ${ }^{\mathrm{L}} \quad$ Per capita value added

Independent variables

Family-managed firm

Municipality size

Control variables

Product innovation

Process innovation

R\&D intensity

Export intensity

Age

Size $^{\mathrm{L}}$

Financial constraints

Listed

Group

Foreign share

Competitors and " 0 " otherwise incorporation
Dummy variable coded " 1 " if two or more family members are involved in the management of the firm

Variable that records the number of inhabitants of the town in which the company has its registered office: less than 2,000; 2,001-10,000; 10,001-50,000; $50,001-500,000$; and more than 500,000 inhabitants

Dummy variable coded " 1 " if the firm has introduced a product innovation and " 0 " otherwise

Dummy variable coded " 1 " if the firm has introduced a process innovation and " 0 " otherwise

Ratio of the firm's R\&D expenditures to sales

Ratio of the firm's foreign sales to total sales

Number of years the firm has existed since its

Firm size as measured by total number of employees

Book value of debt divided by total assets

Dummy variable coded " 1 " if the firm is listed in the stock exchange and 0" otherwise

Dummy variable coded " 1 " if the firm is part of a corporate group and " 0 " otherwise

Foreign shareholding in the firm

Dummy variable coded " 1 " if the firm reported there are more 10 companies with significant market share in the main product market and " 0 " otherwise

Other controls

Industry

Region

Year

Dummies for each two-digit industry

Dummies for each region in which firms are located

Year dummies

\footnotetext{
${ }^{\mathrm{L}}$ Expressed in natural logarithm.
} 


\section{Empirical model}

To test the proposed hypothesis, we use panel data analysis with randomeffects specification. The preference for random-effect models is due to the low 'within' variance of the family status of the firm, which changes very little across time.

With the purpose of investigating the effect of municipality size on the level of productivity of family versus non-family firms, we estimate the following model:

$$
\ln Y_{i, t}=\alpha_{0}+\beta_{1} F_{i, t}+\beta_{2} M_{i, t}+\beta_{3}\left(F_{i, t} \times M_{i, t}\right)+\beta^{\prime} C_{i, t}+\beta^{\prime} T_{i}+\beta^{\prime} S_{i}+\beta^{\prime} \mathrm{R}_{\mathrm{i}}+\varepsilon_{i t},
$$

where

- $\quad i=1, \ldots$.

- $\quad N$ firms,

- $t=1, \ldots$.

- $T$ years,

- $\ln Y$ represents the average labour productivity of firm $I$,

- $F_{i, t}$ is the dummy variable indicating the family status of the firm,

- $M_{i, t}$ indicates the size of the municipality in which firm $i$ is located,

- the interaction $F_{i, t} \times M_{i, t}$ is our key variable of interest,

- $C_{i, t}$ is a vector of the control variables used to capture the influence of the firm's heterogeneity on productivity,

- $\quad T_{i}, S_{i}$, and $R_{i}$ are time-specific, industry-specific, and region-specific dummy effects, respectively,

- $\varepsilon_{i t}$ is the error term.

\section{Results}

The descriptive statistics and pairwise Pearson correlation results are reported in Tables 3.2 and 3.3, respectively. Panel 2A provides the summary statistics for the whole sample. Family-managed firms account for $23 \%$ of the total sample. For a more straightforward depiction of the difference between family and non-family firms, Panel 3B shows the means of the variables grouped by the nature of the firm (family versus non-family), along with the results of a test for differences in the means and the results of the Wilcoxon rank-sum test. Non-family firms are older, bigger, more innovative, more internationalised, and more open to foreign investors than family firms. Additionally, in relation to our firm performance variable-labour productivity — non-family firms are more productive than family firms.

An analysis of the variance inflation factors (VIFs) suggests that multicollinearity is not a concern because all the VIF coefficients are below the generally accepted threshold of 10 , as shown in Table 3.3. 
Table 3.2 Descriptive statistics

Panel 2A: Summary statistics for whole sample

\begin{tabular}{|c|c|c|c|c|c|}
\hline Variable & Obs. & Mean & St. dev. & Min. & Max. \\
\hline Labour productivity ${ }_{\mathrm{I}}^{\mathrm{A}}$ & 21,573 & 51.143 & 56.602 & 0.2 & $3,850.7$ \\
\hline Labour productivity ${ }^{\mathrm{L}}$ & 21,573 & 3.712 & 0.660 & -1.609 & 8,256 \\
\hline Family-managed firm & 21,573 & 0.229 & 0.420 & 0 & 1 \\
\hline Municipality size & 21,573 & 3.137 & 1.096 & 1 & 5 \\
\hline Product innovation & 21,573 & 0.192 & 0.394 & 0 & 1 \\
\hline Process innovation & 21,573 & 0.317 & 0.465 & 0 & 1 \\
\hline$R \& D$ intensity & 21,573 & 0.769 & 2.505 & 0 & 90.924 \\
\hline Export intensity & 21,573 & 22.027 & 28.410 & 0 & 100 \\
\hline Age & 21,573 & 29.139 & 20.267 & 0 & 175 \\
\hline Size & 21,573 & 4.174 & 1.466 & 0 & 9.574 \\
\hline Financial constraints & 21,573 & 54.019 & 23.614 & 0 & 99.979 \\
\hline Listed & 21,573 & .020 & 0.141 & 0 & 1 \\
\hline Group & 21,573 & 0.363 & 0.481 & 0 & 1 \\
\hline Foreign share & 21,573 & 15.430 & 35.233 & 0 & 100 \\
\hline Competitors & 21,573 & 0.675 & 0.468 & 0 & 1 \\
\hline
\end{tabular}

Panel 2B: Difference in means and Wilcoxon rank-sum test

\begin{tabular}{|c|c|c|c|c|c|}
\hline \multirow[t]{2}{*}{ Variable } & \multirow{2}{*}{$\begin{array}{l}\text { Non- } \\
\text { family } \\
\text { firms }\end{array}$} & \multirow{2}{*}{$\begin{array}{l}\text { Family- } \\
\text { managed } \\
\text { firms }\end{array}$} & \multicolumn{2}{|c|}{$\begin{array}{c}\text { Test for difference } \\
\text { of means }\end{array}$} & \multirow{2}{*}{$\begin{array}{l}\text { Wilcoxon rank- } \\
\text { sum test }^{a}\end{array}$} \\
\hline & & & $\begin{array}{l}\text { Difference of } \\
\text { means }\end{array}$ & t-statistics & \\
\hline Labour productivity $^{\mathrm{A}}$ & 53.398 & 43.569 & 9.829 & $10.753^{* * *}$ & $13.745^{* * *}$ \\
\hline Labour productivity ${ }^{\mathrm{L}}$ & 3.743 & 3.609 & 0.134 & $12.615^{* * *}$ & $13.745^{* * *}$ \\
\hline Municipality size & 3.156 & 3.072 & 0.059 & $7.906^{* * *}$ & $5.075^{* * *}$ \\
\hline Product innovation & 0.200 & 0.166 & 0.033 & $5.274^{* * *}$ & $5.271^{* * *}$ \\
\hline Process innovation & 0.322 & 0.301 & 0.021 & $2.798^{* *}$ & $2.798^{* *}$ \\
\hline$R \& D$ intensity & 0.809 & 0.632 & 0.177 & $4.364^{* * *}$ & $13.121^{* * *}$ \\
\hline Export intensity & 23.561 & 16.872 & 6.689 & $14.612^{* * *}$ & $12.772^{* * *}$ \\
\hline Age & 29.311 & 28.559 & 0.752 & $2.292^{* *}$ & -1.001 \\
\hline Size & 4.308 & 3.723 & 0.585 & $25.005^{* * *}$ & $24.463^{* * *}$ \\
\hline Financial constraints & 54.108 & 53.721 & 0.386 & 1.009 & 0.654 \\
\hline Listed & 0.024 & 0.006 & 0.018 & $8.043^{* * *}$ & $8.031^{* * *}$ \\
\hline Group & 0.433 & 0.129 & 0.304 & $40.570^{* * *}$ & $39.107^{* * *}$ \\
\hline Foreign share & 19.551 & 1.592 & 17.958 & $32.227^{* * *}$ & $31.653^{* * *}$ \\
\hline Competitors & 0.689 & 0.629 & 0.059 & $7.906^{* * *}$ & $7.896^{* * *}$ \\
\hline Observations & 16,623 & 4,950 & & & \\
\hline
\end{tabular}

${ }^{\mathrm{A}}$ Expressed in absolute terms. ${ }^{\mathrm{L}}$ Expressed in natural logarithm.

Level of statistical significance: $+p<0.10,{ }^{*} p<0.05,{ }^{* *} p<0.01,{ }^{* * *} p<0.001$. ${ }^{\text {a }}$ The Wilcoxon rank-sum test analyses whether the two samples are from different distributions (Sample 1: non-family firms; Sample 2: family-managed firms). 


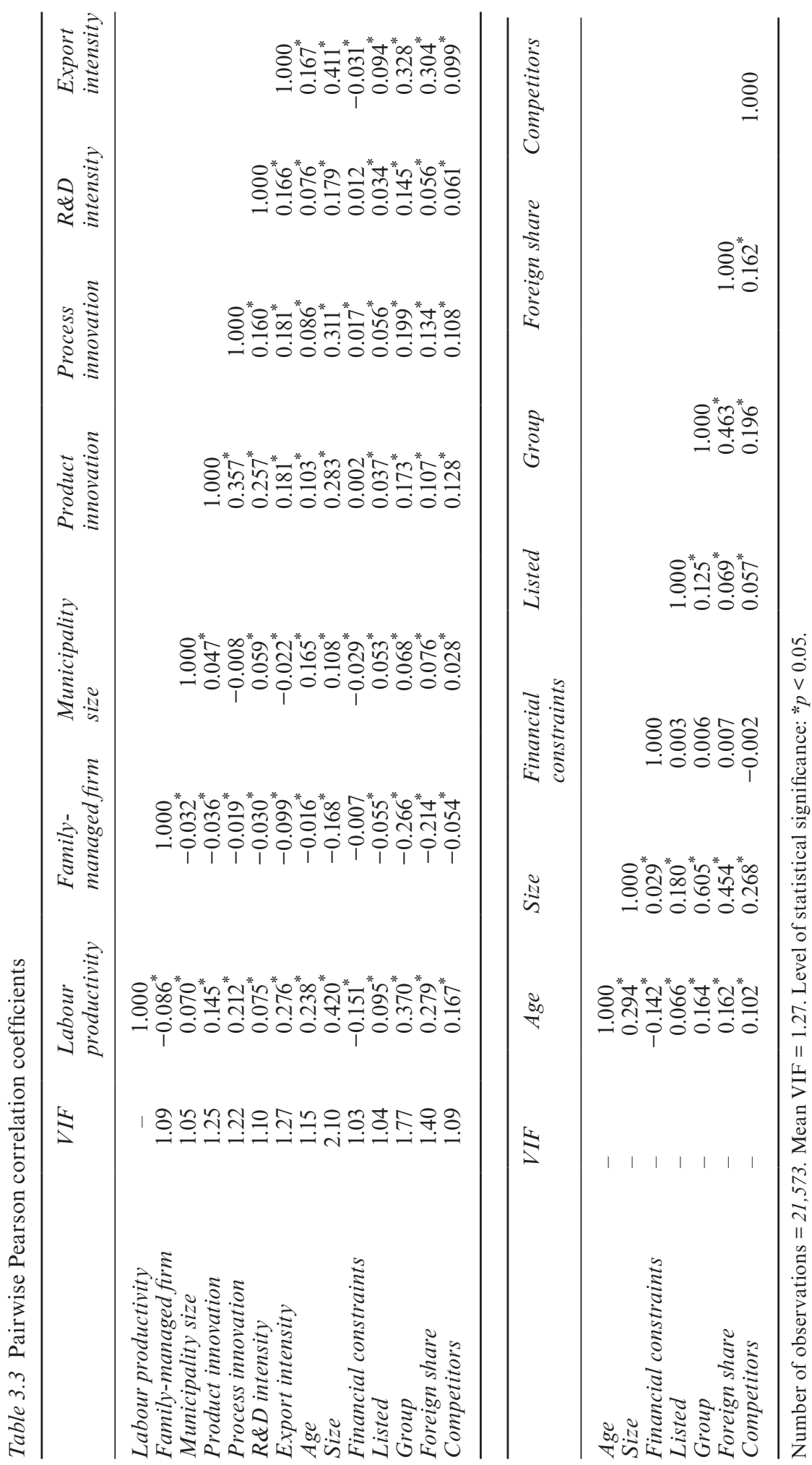


Table 3.4 Family-managed firms, labour productivity, and municipality size

\begin{tabular}{|c|c|c|c|}
\hline & Model 1 & Model 2 & Model 3 \\
\hline \multirow[t]{2}{*}{ Product innovation } & 0.016 & 0.016 & 0.015 \\
\hline & $(0.011)_{* * *}$ & $(0.011)_{* * *}$ & $(0.011)_{* * *}$ \\
\hline \multirow[t]{2}{*}{ Process innovation } & $0.039^{* * *}$ & $0.039^{* * *}$ & $0.039^{* * *}$ \\
\hline & $(0.008)^{* * *}$ & $(0.008)^{* * *}$ & $(0.008)_{* * *}$ \\
\hline$R \& D$ intensity & $\begin{array}{l}-0.017 \\
(0.003)\end{array}$ & $\begin{array}{l}-0.017 \\
(0.003)\end{array}$ & $\begin{array}{l}-0.017 \\
(0.003)\end{array}$ \\
\hline Export intensity & $\begin{array}{l}0.001^{* * * *} \\
(0.000)\end{array}$ & $\begin{array}{l}0.001^{* * *} \\
(0.000)\end{array}$ & $\begin{array}{l}0.001^{* * *} \\
(0.000)\end{array}$ \\
\hline Age & $\begin{array}{l}0.001^{*} \\
(0.000)\end{array}$ & $\begin{array}{l}0.001^{*} \\
(0.000)\end{array}$ & $\begin{array}{l}0.001^{*} \\
(0.000)\end{array}$ \\
\hline Size & $\begin{array}{l}0.108^{* * *} \\
(0.008)\end{array}$ & $\begin{array}{l}0.107^{* * *} \\
(0.008)\end{array}$ & $\begin{array}{l}0.107^{* * *} \\
(0.008)\end{array}$ \\
\hline Financial constraints & $\begin{array}{l}-0.003^{* * *} \\
(0.000)\end{array}$ & $\begin{array}{l}-0.003^{* * *} \\
(0.000)\end{array}$ & $\begin{array}{l}-0.003^{\text {*** }} \\
(0.000)\end{array}$ \\
\hline Listed & $\begin{array}{l}-0.070^{+} \\
(0.042)\end{array}$ & $\begin{array}{l}-0.072^{+} \\
(0.042)\end{array}$ & $\begin{array}{l}-0.073^{+} \\
(0.042)\end{array}$ \\
\hline Group & $\begin{array}{l}0.076^{* * * *} \\
(0.016)\end{array}$ & $\begin{array}{l}0.076^{* * *} \\
(0.015)\end{array}$ & $\begin{array}{l}0.076^{* * * *} \\
(0.015)\end{array}$ \\
\hline Foreign share & $\begin{array}{l}0.001^{* *} \\
(0.000)\end{array}$ & $\begin{array}{l}0.001^{* *} \\
(0.000)\end{array}$ & $\begin{array}{l}0.001^{* *} \\
(0.000)\end{array}$ \\
\hline Competitors & $\begin{array}{l}0.033^{* *} \\
(0.010)\end{array}$ & $\begin{array}{l}0.033^{* *} \\
(0.010)\end{array}$ & $\begin{array}{l}0.033^{* *} \\
(0.010)\end{array}$ \\
\hline Family-managed firm & $\begin{array}{l}-0.005 \\
(0.011)\end{array}$ & $\begin{array}{l}-0.004 \\
(0.011)\end{array}$ & $\begin{array}{l}0.066^{+} \\
(0.036)\end{array}$ \\
\hline \multicolumn{2}{|l|}{ Municipality size } & $\begin{array}{l}0.011^{+} \\
(0.006)\end{array}$ & $\begin{array}{l}0.015^{*} \\
(0.007)\end{array}$ \\
\hline $\begin{array}{l}\text { Family-managed } \\
\quad \text { firm } \times \text { Municipality size }\end{array}$ & & & $\begin{array}{l}-0.023^{*} \\
(0.011)\end{array}$ \\
\hline Regions & Yes & Yes & Yes \\
\hline Industry & Yes & Yes & Yes \\
\hline Years & Yes & Yes & Yes \\
\hline Constant & $\begin{array}{l}2.984^{* * *} \\
(0.059)\end{array}$ & $\begin{array}{l}2.957^{* * *} \\
(0.062)\end{array}$ & $\begin{array}{l}2.940^{* * *} \\
(0.063)\end{array}$ \\
\hline WaldChi2 & $2,657.83$ & $2,679.09$ & $2,681.74$ \\
\hline Prob $>$ Chi 2 & 0.0000 & 0.0000 & 0.0000 \\
\hline Number of firms & 3,331 & 3,331 & 3,331 \\
\hline Observations & 21,573 & 21,573 & 21,573 \\
\hline
\end{tabular}

The table presents random-effect models based on a panel dataset of firm with at least 10 employees over the 2002-2015 period. Robust standard errors are reported in parentheses. Level of statistical significance: $+p<0.10,{ }^{*} p<0.05,{ }^{* *} p<0.01,{ }^{* * *} p<0.001$.

The results of the econometric analysis are reported in Table 3.4. In Model 1, we introduce all control variables and our main exploratory variable-family-managed firm. We observe that process innovation, export, age, size, foreign share, being part of a group, and being listed positively 


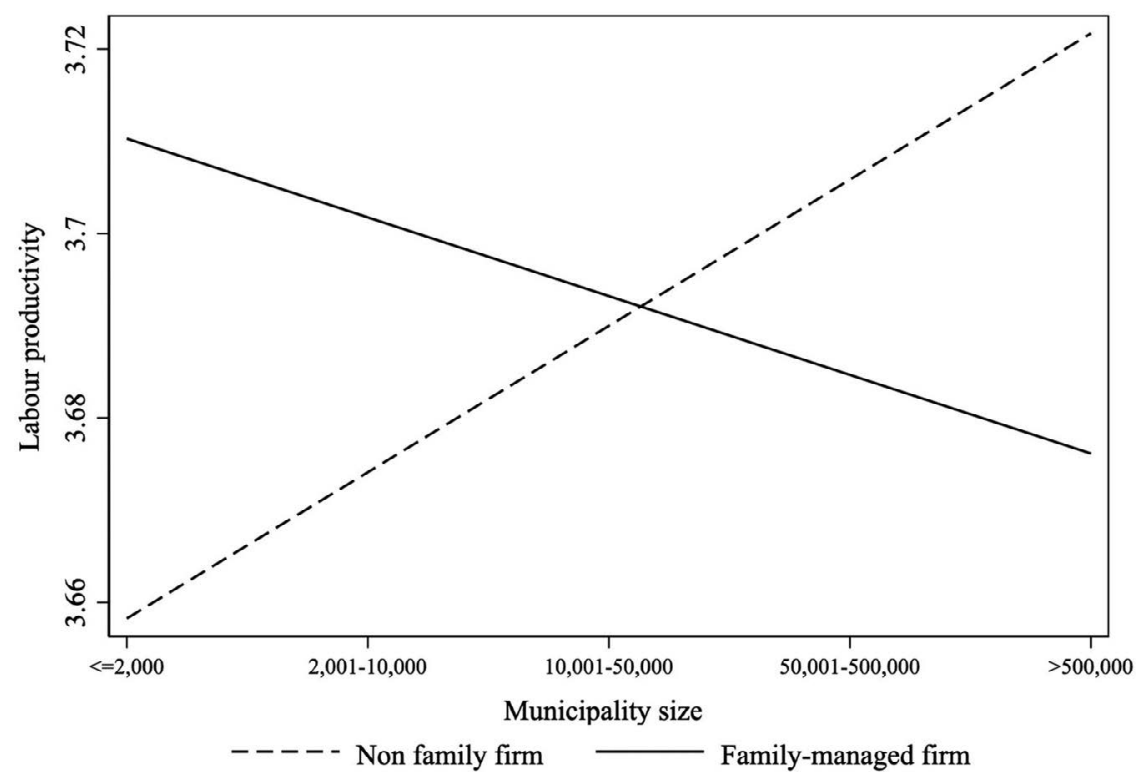

Figure 3.1 Labour productivity of family versus non-family firms across municipalities.

affect firms' labour productivity. Conversely, R\&D intensity and financial constraints firm performance. Additionally, even though the family firm coefficient is negative, it is not significant.

In Model 2, we introduce our moderator variable - municipality sizewhich has a positive and significant relationship with labour productivity $(\beta=0.011, p<0.10)$. This result suggests that municipality size is source of increasing returns to city scale in general, hence providing support for urbanisation economies (Fu \& Hong, 2011). Finally, in Model 3, we test our hypothesis by introducing the moderating effect of municipality size. The interaction term is negative and statistically significant $(\beta=-0.023$, $p<0.05$ ), which suggests that municipality size has an adverse effect on family firms' productivity.

For a more straightforward interpretation of this result, we plot the two-way interaction in Figure 3.1. We observe that municipality size has antithetical effect on the productivity of the two types of firms - family and non-family firms. In particular, family-managed firms appear to be more productive in small municipalities than non-family firms, with their performance decreasing with an increase in city scale. Conversely, non-family firms benefit of the size of the municipalities in which they are located.

We perform a sensitivity analysis to corroborate our results. Specifically, in lieu of the dichotomous variable, we use a continuous measure of family involvement (Family management) to capture the number of family members 
Table 3.5 Robustness check: Family management, labour productivity, and municipality size

\begin{tabular}{|c|c|c|c|}
\hline & Model 1 & Model 2 & Model 3 \\
\hline Product innovation & $\begin{array}{l}0.016 \\
(0.011)\end{array}$ & $\begin{array}{l}0.016 \\
(0.011)\end{array}$ & $\begin{array}{l}0.015 \\
(0.011)\end{array}$ \\
\hline Process innovation & $0.039^{* * * *}$ & $0.039^{* * * *}$ & $0.039^{* * *}$ \\
\hline$R \& D$ intensity & $\begin{array}{l}(0.008)^{* * *} \\
-0.017^{* * *} \\
(0.003)\end{array}$ & $\begin{array}{l}(0.008)^{* * *} \\
-0.017^{* *} \\
(0.003)\end{array}$ & $\begin{array}{l}(0.008)^{* * *} \\
-0.017^{* *} \\
(0.003)\end{array}$ \\
\hline Export intensity & $\begin{array}{l}0.001^{* * *} \\
(0.000)\end{array}$ & $\begin{array}{l}0.001^{* * *} \\
(0.000)\end{array}$ & $\begin{array}{l}0.001^{* * *} \\
(0.000)\end{array}$ \\
\hline Age & $\begin{array}{l}0.001^{*} \\
(0.000)\end{array}$ & $\begin{array}{l}0.001^{*} \\
(0.000)\end{array}$ & $\begin{array}{l}0.001^{*} \\
(0.000)\end{array}$ \\
\hline Size & $\begin{array}{l}0.108^{* * *} \\
(0.008)\end{array}$ & $\begin{array}{l}0.107^{* * *} \\
(0.008)\end{array}$ & $\begin{array}{l}0.107^{* * *} \\
(0.008)\end{array}$ \\
\hline Financial constraints & $-0.003^{* * *}$ & $-0.003^{* * *}$ & $-0.003^{* * *}$ \\
\hline Listed & $\begin{array}{l}-0.071^{+} \\
(0.042)\end{array}$ & $\begin{array}{l}-0.072^{+} \\
(0.042)\end{array}$ & $\begin{array}{l}-0.073^{+} \\
(0.041)\end{array}$ \\
\hline Group & $\begin{array}{l}0.075^{* * *} \\
(0.016)\end{array}$ & $\begin{array}{l}0.075^{* * *} \\
(0.015)\end{array}$ & $\begin{array}{l}0.075^{* * *} \\
(0.015)\end{array}$ \\
\hline Foreign share & $\begin{array}{l}0.001^{* *} \\
(0.000)\end{array}$ & $\begin{array}{l}0.001^{* * *} \\
(0.000)\end{array}$ & $\begin{array}{l}0.001^{* * *} \\
(0.000)\end{array}$ \\
\hline Competitors & $\begin{array}{l}0.033^{* *} \\
(0.010)\end{array}$ & $\begin{array}{l}0.033^{* *} \\
(0.010)\end{array}$ & $\begin{array}{l}0.033^{* *} \\
(0.010)\end{array}$ \\
\hline Family management & $\begin{array}{l}-0.003 \\
(0.005)\end{array}$ & $\begin{array}{r}-0.003 \\
(0.005)\end{array}$ & $\begin{array}{l}0.029^{*} \\
(0.014)\end{array}$ \\
\hline Municipality size & & $\begin{array}{l}0.011^{+} \\
(0.006)\end{array}$ & $\begin{array}{l}0.018^{*} \\
(0.007)\end{array}$ \\
\hline $\begin{array}{l}\text { Family management } \\
\quad \times \text { Municipality size }\end{array}$ & & & $\begin{array}{l}-0.011^{*} \\
(0.004)\end{array}$ \\
\hline Regions & Yes & Yes & Yes \\
\hline Industry & Yes & Yes & Yes \\
\hline Years & Yes & Yes & Yes \\
\hline Constant & $\begin{array}{l}2.987^{* * *} \\
(0.060)\end{array}$ & $\begin{array}{l}2.959^{* * *} \\
(0.062)\end{array}$ & $\begin{array}{l}2.933^{* * *} \\
(0.063)\end{array}$ \\
\hline WaldChi2 & $2,660.24$ & $2,681.40$ & $2,686.07$ \\
\hline Prob $>$ Chi2 & 0.0000 & 0.0000 & 0.0000 \\
\hline Number of firms & 3,331 & 3,331 & 3,331 \\
\hline Observations & 21,573 & 21,573 & 21,573 \\
\hline
\end{tabular}

The table presents random-effect models based on a panel dataset of firms with at least $10 \mathrm{em}$ ployees over the 2002-2015 period. Family management is a continuous variable that counts the number of family members in managerial positions. Robust standard errors are reported in parentheses. Level of statistical significance: $+p<0.10,{ }^{*} p<0.05,{ }^{* *} p<0.01,{ }^{* * *} p<0.001$.

in managerial position. Table 3.5 confirms our previous results - that is, family firm performance is negatively affected by municipality size, with the differential of productivity between the two types of firms being particularly large in small municipality. 


\section{Conclusion}

One of the main research questions that family business scholars have focused on is whether the family firm is a better form of business organisation than the non-family firm. Because current findings comparing family and non-family firm performance are contradictory (Mazzi, 2011), in this book chapter, we addressed the call made by Amato et al. (2020) to include some contextual dimensions to tease out when and where family and non-family firms have superior performance.

Our main theoretical reasoning is that family and non-family firms are able to exploit their competitive advantages in different external environments. That is, each type of firm can materialise their strengths and reduce their weaknesses in different ways depending on the socio-spatial contexts in which they are located (Cucculelli \& Storai, 2015), the set of formal and informal institutions defining the 'rules of the game' in their societies (Soleimanof, Rutherford, \& Webb, 2018), and particular events or historical periods (Smith, 2016). More specifically, in this chapter, we explored the family firm-territory nexus stemming from being located in cities, as a particular type of socio-spatial context (Capello, 2002). By drawing on the regional familiness approach (Basco, 2015), we posited that family firms are better positioned to benefit from proximity dimensions (i.e., geographical, social, and cognitive) arising from being located in small urban areas than from the resulting agglomeration economies. Because of their territorial embeddedness and socio-emotional characteristics, family firms are in a superior position to exploit economic opportunities, facilitate the exchange of tacit knowledge, and acquire tangible and intangible resources in peripheral areas, such as in small municipalities, where access to agglomerations is normally more difficult.

Our findings reveal that family firms' labour productivity is strongly affected by the size of the municipalities in which they dwell - a proxy for the continuum between proximity economies and urbanisation economies. In particular, while family firms' productivity is negatively associated with municipality size, non-family firms benefit from increasing returns to city scale. Our results are in line with previous studies (Backman \& Palmberg, 2015; Baù et al., 2019) that show that family firms located in sparsely populated areas, such as rural ones, have better performance than non-family firms. Taken together, this evidence shows how reciprocal trust-based relationships established both among family members and between family firms and their immediate surroundings equip them with unique locational advantages as compared to non-family firms.

\section{Contributions}

Our book chapter makes important contributions to theory and practice. First, it contributes to the family business field by shedding new light on the micro-territorial foundations of family firms. In particular, our empirical 
evidence supports the view that family firms are inherently spatial. That is, they are distinctly responsive to geographic fragmentation and spatial variation in terms of resource availability and business opportunities, both of which are strongly related to the size of the municipalities in which firms are located (Backman \& Palmberg, 2015). At the same time, family firms are inherently local, meaning they are deeply anchored in territorially bounded areas. Family firms' embeddedness in localised networks of relationships results in a superior position to leverage the advantages of external proximity dimensions and, hence, leads to them having competitive advantages in small municipalities.

Second, our research contributes to regional studies specifically by introducing family firms in the debate on urbanisation economies and local economies (economies of proximity). While firm size and industry have been extensively explored in this respect (Fu \& Hong, 2011; Henderson et al., 1995), our chapter highlights the opportunity to take the firms' family status into account to better comprehend Jacobs externalities. Additionally, given the prevalent view that regional development ultimately stems from the balanced growth of individual cities (Capello, 2009), regional scholars' acknowledgment of family firms could provide new insights into the role these organisations play in the competitiveness and sustainability of urban settings.

Finally, our chapter has important contributions for policymakers. Based on our evidence, policymakers should be aware of different types of economic actors (e.g., family and non-family firms) when tailoring polices to develop prosperous, diversified, and sustainable regions because the demographics of economic structures may determine the effectiveness of policies. For instance, since diversified urban environments have an asymmetrical effect on firm performance - the benefits of urbanisation are better exploited by non-family firms than family firms. On the other hand, family firms are better positioned to leverage the external advantages of proximity in small municipalities. Therefore, development policies should be designed carefully, taking into consideration both the territory and the economic actors who form the economic structure of the territory itself.

\section{Limitations and future lines of research}

Our research is not exempt from having limitations, which in turn pave the way for future lines of research. First, our contextual variable (i.e., municipality size) represents only a partial measure of urban agglomerations. Even though municipality size is strongly related to the degree of diversification of urban settings, future research should employ a finer-grained measure of urban diversity and simultaneously test the effect of urban size and industrial diversity on family firm performance (Fu \& Hong, 2011). Second, because cities are sources of dynamic economies as reflected in the higher innovativeness of co-located firms (Capello, 2002), future studies should explore whether and to what extent family-managed firms' innovation outputs 
(e.g., patents) are affected by urban agglomerations. Finally, future research could improve the classification of firms. In this chapter, our main classification comprised family and non-family firms, but we know this is only a rough measure to capture the heterogeneity among economic actors. Within family and non-family firms, there are sub-classifications capable of producing richer information. Regarding family firms, not all are alike, and different types may react differently to and be affected differently by the socio-spatial contexts in which they are located (Smith, 2016). For instance, generational involvement and level of 'familiness' are two traditional dimensions used to capture different types of family firms that account for family firms' heterogeneity in terms of both demographics and competitive advantages (Habbershon \& Williams, 1999).

\section{Notes}

1 The survey began in 1990, with the Spanish economy as a whole as its geographical scope of reference. In particular, ESEE employs yearly variables covering the following eight business categories: (1) activity, products, and manufacturing processes; (2) customers and suppliers; (3) costs and prices; (4) markets served; (5) technological activities; (6) foreign trade; (7) employment; and (8) accounting data. For more information, please visit: https://www.fundacionsepi.es/investigacion/esee/en/spresentacion.asp.

2 NACE is the acronym for Nomenclature statistique des activités économiques dans la Communauté européenne and represents the European standard classification of productive economic activity.

3 NUTS stands for Nomenclature of Territorial Units for Statistics and represents the levels of territorial division. The Spanish territory is classified into the following levels: NUTS 1, consisting of seven groups of autonomous communities (Agrupación de comunidades autónomas); NUTS 2, comprising 19 autonomous communities and cities (Comunidades y ciudades autónomas); and NUTS 3, comprising 59 provinces, islands, Ceuta, and Melilla (Provincias, Islas, Ceuta y Melilla). However, ESEE excludes the autonomous cities of Ceuta and Melilla; hence, there are 17 autonomous communities.

4 It is worth noting that, even though the size of a city is strongly related to its diversity, it is very common to explicitly consider the degree of urban diversification, gener-

ally expressed as 1 minus the Herfindahl index in terms of employment in one-digit industries in a given city: Urban diversity $=1-\sum_{m=1}^{M}\left(E_{m k} / \sum_{m=1}^{M} E_{m k}\right)^{2}$, where $E_{m k}$ is the number of employees in one-digit industry $m$ in city $k$, and $M$ is the total number of one-digit industries in city $k$. The value of urban diversity ranges from 0 to 1 , with a value closer to 1 suggesting more diversification of the urban setting.

\section{References}

Adjei, E. K., Eriksson, R. H., \& Lindgren, U. (2016). Social proximity and firm performance: The importance of family member ties in workplaces. Regional Studies, Regional Science, 3(1), 303-319. 
Amato, S., Basco, R., \& Lattanzi, N. (2020). Contextualizing employment outcomes in family business research: Current findings and future research avenues. Sharjah: American University of Sharjah.

Amato, S., Basco, R., Gómez-Ansón, S., \& Lattanzi, N. (2020). Family-managed firms and employment growth during an economic downturn: Does their location matter? Baltic Journal of Management, 15(4), 607-630.

Aparicio, G., Basco, R., Iturralde, T., \& Maseda, A. (2017). An exploratory study of firm goals in the context of family firms: An institutional logics perspective. Journal of Family Business Strategy, 8(3), 157-169.

Backman, M., \& Palmberg, J. (2015). Contextualizing small family fi rms: How does the urban - rural context affect fi rm employment growth? Journal of Family Business Strategy, 6, 247-258.

Basco, R. (2013). The family's effect on family firm performance: A model testing the demographic and essence approaches. Journal of Family Business Strategy, 4(1), 42-66.

Basco, R. (2015). Family business and regional development - A theoretical model of regional familiness. Journal of Family Business Strategy, 6(4), 259-271.

Basco, R. (2017). "Where do you want to take your family firm?" A theoretical and empirical exploratory study of family business goals. BRQ Business Research Quarterly, 20(1), 28-44.

Bathelt, H., \& Gluckler, J. (2003). Toward a relational economic geography. Journal of Economic Geography, 3(2), 117-144.

Baù, M., Chirico, F., Pittino, D., Backman, M., \& Klaesson, J. (2019). Roots to grow: Family firms and local embeddedness in rural and urban contexts. Entrepreneurship Theory and Practice, 43(2), 360-385.

Boschma, R. A. (2005). Proximity and innovation: A critical assessment. Regional Studies, 39(1), 61-74.

Capello, R. (2002). Entrepreneurship and spatial externalities: Theory and measurement. The Annals of Regional Science, 36(3), 387-402.

Capello, R. (2009). Spatial spillovers and regional growth: A cognitive approach. European Planning Studies, 17(5), 639-658.

Capello, R., \& Faggian, A. (2005). Collective learning and relational capital in local innovation processes. Regional Studies, 39(1), 75-87.

Cucculelli, M., \& Storai, D. (2015). Family firms and industrial districts: Evidence from the Italian manufacturing industry. Journal of Family Business Strategy, 6(4), 234-246.

$\mathrm{Fu}, \mathrm{S} .$, \& Hong, J. (2011). Testing urbanization economies in manufacturing industries: Urban diversity or urban size? Journal of Regional Science, 51(3), 585-603.

Galliano, D., Magrini, M., \& Triboulet, P. (2015). Marshall's versus Jacobs' externalities in firm innovation performance: The case of French industry. Regional Studies, 49(11), 1840-1858.

Gao, T. (2004). Regional industrial growth: Evidence from Chinese industries. Regional Science and Urban Economics, 34(1), 101-124.

Gomez-Mejia, L. R., Cruz, C., Berrone, P., \& De Castro, J. (2011). The bind that ties: Socioemotional wealth preservation in family firms. Academy of Management Annals, 5(1), 653-707.

Gomez-Mejia, L. R., Basco, R., Müller, C., \& Gonzalez, A. C. (2020). Family business and local development in Iberoamerica. Cross-Cultural Management Journal, 27(2), 121-136. 
Gordon, I. R., \& McCann, P. (2000). Industrial clusters: Complexes, agglomeration and/or social networks? Urban Studies, 37(3), 513-532.

Habbershon, T. G., \& Williams, M. L. (1999). A resource-based framework for assessing the strategic advantages of family firms. Family Business Review, 12(1), $1-25$.

Henderson, V., Kuncoro, A., \& Turner, M. (1995). Industrial development in cities. Journal of Political Economy, 103(5), 1067-1090.

Hess, M. (2004). "Spatial" relationships? Towards a reconceptualization of embeddedness. Progress in Human Geography, 28(2), 165-186.

James, A. E., Hadjielias, E., Guerrero, M., Discua Cruz, A., \& Basco, R. (2020). Entrepreneurial families in business across generations, context, and cultures. Journal of Family Business Management, forthcoming.

Jofre-Monseny, J., Marín-López, R., \& Viladecans-Marsal, E. (2014). The determinant of localization and urbanization economies: evidence from the location of new firms in Spain. Journal of Regional Science, 54(2), 313-337.

Krueger, N., Bogers, M., Labaki, R., \& Basco, R. (2020). Advancing family business science through context theorizing: The case of the Arab World. Journal of Family Business Strategy, forthcoming.

Lähdesmäki, M., Siltaoja, M., \& Spence, L. J. (2019). Stakeholder salience for small businesses: A social proximity perspective. Journal of Business Ethics, 158(2), 373-385.

Martin, R., \& Simmie, J. (2008). The theoretical bases of urban competitiveness: Does proximity matter? Revue d'Économie Régionale \& Urbaine, Octobre(3), 333.

Mazzi, C. (2011). Family business and financial performance: Current state of knowledge and future research challenges. Journal of Family Business Strategy, 2(3), 166-181.

Parr, J. B. (2002). Missing elements in the analysis of agglomeration economies. International Regional Science Review, 25(2), 151-168.

Parr, J. B. (2007). Spatial definitions of the city: Four perspectives. Urban Studies, 44(2), 381-392.

Smith, C. (2016). Environmental jolts: Understanding how family firms respond and why. Family Business Review, 29(4), 401-423.

Soleimanof, S., Rutherford, M. W., \& Webb, J. W. (2018). The intersection of family firms and institutional contexts: A review and agenda for future research. Family Business Review, 31(1), 32-53.

Stough, R., Welter, F., Block, J., Wennberg, K., \& Basco, R. (2015). Family business and regional science: "Bridging the gap." Journal of Family Business Strategy, 6(4), 208-218.

Welter, F. (2011). Contextualizing entrepreneurship-conceptual challenges and ways forward. Entrepreneurship Theory and Practice, 35(1), 165-184.

Westlund, H., \& Adam, F. (2010). Social capital and economic performance: A meta-analysis of 65 studies. European Planning Studies, 18(6), 893-919.

Williams, R. I., Pieper, T. M., Kellermanns, F. W., \& Astrachan, J. H. (2019). Family business goal formation: A literature review and discussion of alternative algorithms. Management Review Quarterly, 69(3), 329-349. 